\title{
VIM wt Allele
}

National Cancer Institute

\section{Source}

National Cancer Institute. VIM wt Allele. NCI Thesaurus. Code C52442.

Human VIM wild-type allele is located in the vicinity of $10 \mathrm{p} 13$ and is approximately $8 \mathrm{~kb}$ in length. This allele, which encodes vimentin protein, plays a role in the maintenance of the cellular structure of mesenchymal tissues. 